INTERNATIONAL MULTIDISCIPLINARY SCIENTIFIC GEOCONFERENCES 17-26 June, 2014, Bulgaria

14th GeoConference on INFORMATICS, GEOINFORMATICS AND REMOTE SENSING Conference Proceedings Volume I

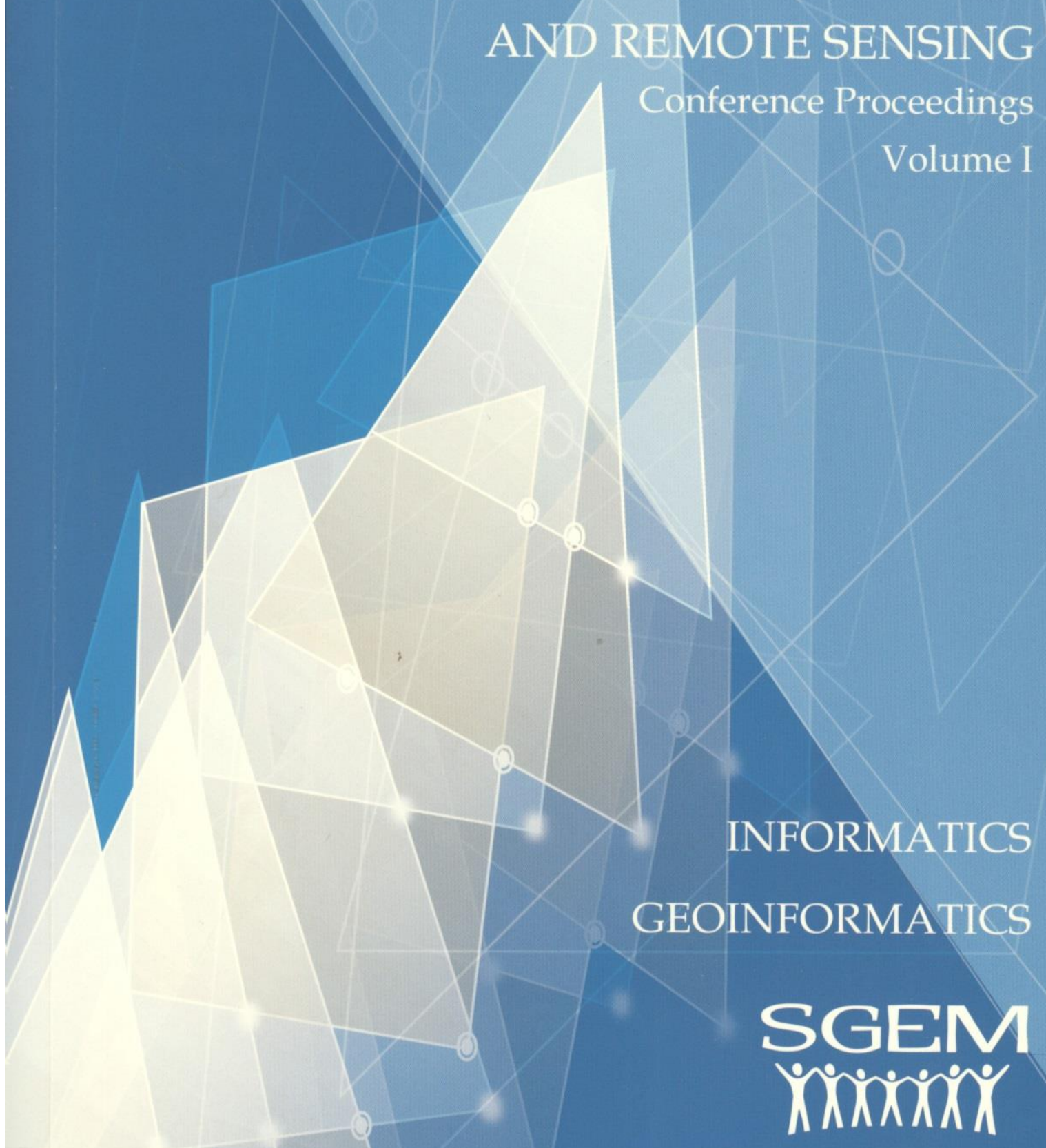




\section{DISCLAIMER}

This book contains abstracts and complete papers approved by the Conference Review Committee. Authors are responsible for the content and accuracy.

Opinions expressed may not necessarily reflect the position of the International Scientific Council of SGEM.

Information in the SGEM 2014 Conference Proceedings is subject to change without notice. No part of this book may be reproduced or transmitted in any form or by any means, electronic or mechanical, for any purpose, without the express written permission of the International Scientific Council of SGEM.

Copyright (C) SGEM2014

All Rights Reserved by the International Multidisciplinary Scientific GeoConference SGEM Published by STEF92 Technology Ltd., 1 “Andrey Lyapchev” Blvd., 1797 Sofia, Bulgaria Total print: 5000

ISBN 978-619-7105-10-0

ISSN 1314-2704

DOI: 10.5593/sgem2014B21

INTERNATIONAL MULTIDISCIPLINARY SCIENTIFIC GEOCONFERENCE SGEM Secretariat Bureau

$\begin{array}{ll}\text { Phone: } & +35929753982 \\ \text { Fax: } & +35928741088 \\ & \\ \text { E-mails: } & \text { sgem@sgem.org | sgem@stef92.com } \\ \text { URL: } & \text { www.sgem.org }\end{array}$




\section{CONFERENCE ORGANIZERS}

- BULGARIAN ACADEMY OF SCIENCES

- ACADEMY OF SCIENCES OF THE CZECH REPUBLIC

- LATVIAN ACADEMY OF SCIENCES

- POLISH ACADEMY OF SCIENCES

- RUSSIAN ACADEMY OF SCIENCES

- SERBIAN ACADEMY OF SCIENCES AND ARTS

- SLOVAK ACADEMY OF SCIENCES

- NATIONAL ACADEMY OF SCIENCES OF UKRAINE

- INSTITUTE OF WATER PROBLEM AND HYDROPOWER OF NAS KR

- NATIONAL ACADEMY OF SCIENCES OF ARMENIA

- SCIENCE COUNCIL OF JAPAN

- THE WORLD ACADEMY OF SCIENCES (TWAS

- EUROPEAN ACADEMY OF SCIENCES, ARTS AND LETTERS

- ACADEMY OF SCIENCES OF MOLDOVA

- MONTENEGRIN ACADEMY OF SCIENCES AND ARTS

- CROATIAN ACADEMY OF SCIENCES AND ARTS, CROATIA

- GEORGIAN NATIONAL ACADEMY OF SCIENCES

- ACADEMY OF FINE ARTS AND DESIGN IN BRATISLAVA

- TURKISH ACADEMY OF SCIENCES

- BULGARIAN INDUSTRIAL ASSOCIATION

- BULGARIAN MINISTRY OF ENVIRONMENT AND WATER

\section{HONORED ORGANIZER}

Aिस्मी BULGARIAN ACADEMY OF SCIENCES

\section{EXCLUSIVE SUPPORTING PARTNER}

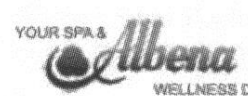

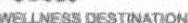

\section{INTERNATIONAL SCIENTIFIC COMMITTEE}

Informatics, Geoinformatics and Remote Sensing

- PROF. ING. ALEŠ ČEPEK, CSC., CZECH REPUBLIC

- PROF. G. BARTHA, HUNGARY

- PROF. DR. DAMIR MEDAK, CROATIA

- PROF. PETER REINARTZ, GERMANY

- PROF. DR. JÓZSEF ÁDAM, HUNGARY

- PROF. RUI MIGUEL MARQUES MOURA, PORTUGAL

- PROF. DR. ISIK YILMAZ, TURKEY

- PROF. DR. ING. KAREL PAVELKA, CZECH REPUBLIC

- PROF. DR. MARCEL MOJZES, SLOVAKIA 
- ASSOC. PROF. DR MILAN HOREMUZ, SWEDEN

- DR. TIBERIU RUS, ROMANIA

- DR. MARKO KREVS, SLOVENIA 
Seipel, University of Gaevle Department of Industrial Development IT and Land Management, Sweden.

113. TOWARDS A FRAMEWORK FOR SIMULATION-BASED EVALUATION OF PERSONAL DECISION SUPPORT SYSTEMS FOR FLOOD EVACUATION, Dr. Konstantin Knyazkov, Marina Balakhontceva, Dr. Sergey Ivanov, University ITMO, Russia . .883

114. TRAFFIC INTENSITY CHANGES AND THEIR INFLUENCE ON SPATIAL DISTRIBUTION OF SUBURBANIZATION, Dr. Jaroslav Burian, Msc. Lenka Zajickova, dr. Pavel Tucek, prof. Vit Vozenilek, BSc. Barbora Langrova, dr. Mukesh Boori, Palacky University in Olomouc, Czech Republic .895

115. TWO ACCESS DATABASES ORGANIZATION FOR SASA LEAD-ZINC DEPOSIT AND TAILINGS, REPUBLIC OF MACEDONIA, M.Sc Dalibor Serafimovski, Prof. Vlado Gicev, Prof. Kosta Mitreski, University Goce Delcev, FYR of Macedonia .903

116. USE OF GEOGRAPHIC INFORMATION SYSTEMS FOR ASSESSMENT OF GROUNDWATER QUALITY IN INDUSTRIAL HUBS, Prof. Vladimir Nemtinov, Assoc. Prof. Yulia Nemtinova, Assoc. Prof. Andrey Borisenko, Kirill Nemtinov, Tambov State Technical University, Russia 911

117. VECTOR MAP OBJECTS RECOGNITION BASED ON A HIERARCHY OF TOPOLOGICAL RELATIONSHIPS, Assist. Prof. Sergey Eremeev, Murom Institute of Vladimir State University, Russia

118. VIBROSEISMOACOUSTIC METHOD IN STUDYING OF GEOPHYSICAL FIELDS INTERACTION IN GROUND ATMOSPHERE,

Prof. Dr. Marat Khairetdinov, Dr. Valerii Kovalevsky, St. Ph. D. assistant Gyulnara Voskoboinikova, St. Ph. D. assistant Galina Sedukhina, Novosibirsk State Technical University, Russia.. .925 


\title{
TWO ACCESS DATABASES ORGANIZATION FOR SASA LEAD-ZINC DEPOSIT AND TAILINGS, REPUBLIC OF MACEDONIA
}

\author{
M. Sc. Dalibor Serafimovski ${ }^{1}$ \\ Full. Prof. Dr. Vlado Gičev ${ }^{1}$ \\ Full Prof. Dr. Kosta Mitreski \\ ${ }^{1}$ Faculty of Computer Science, University "Goce Delčev"-Štip, R. Macedonia \\ ${ }^{2}$ Faculty of Computer Science and Engineering, University "Ss.Cyril and Methodius" Skopje, \\ R. Macedonia
}

\begin{abstract}
Within the Republic of Macedonia there are numerous polymetallic mineral deposits important for its economy. This paper focuses on efforts we made to organize Microsoft Access database with the most representative data for the most important $\mathrm{Pb}-\mathrm{Zn}$ deposit in the Republic of Macedonia, the Sasa deposit and mine near the city of Makedonska Kamenica. First of all, with the software package "Microsoft Access" we have organized database with information of the most important geological, metallogenic and economic features of the deposit. Also, we have not omitted the fact that each active mine exploitation has been followed with production of significant anthropogenic input to the environment, so we have structured and anthropogenic database too. Both databases were adapted for simple and sophisticated querying of particular deposit and anthropogenic features and allows edition of reports and a geographic display of the queried information.
\end{abstract}

Keywords: mineral deposit, Access database, reserves, anthropogenic concentrations .

\section{INTRODUCTION}

Here we would like to stress that in the Republic of Macedonia there are several polymetallic deposits that has been exploited during last six decades. Mainly those were lead-zinc, copper and nickel deposits, followed by some other deposits of smaller economic significance. The most important lead-zinc deposit for Macedonia and adjacent region used to be the Sasa deposit near the city of Makedonska Kamenica. To be honest, up to date, in the Republic of Macedonia there weren't professional databases that should be in accordance to the European directives, although there is an initiative in ours Ministry of Economy that such database(s) should be prepared and included in similar modern European databases (ex. Mineral database at the BRGM, France).

We were aiming to organize both databases with an information about some of the most representative Sasa deposit feautures, regarding natural and anthropogenic issues. Bearing in mind that the Sasa deposit and mine have a long history of exploration and exploitation, we knew that building aforementioned databases is not an easy task to fulfill. We had to systematize data from exploration longer than seven decades and exploitation longer than half a century. Also, we were aware of the problem with environmental pollution around the Sasa deposit and mine, which has been generaly 
related to adit waste water outflow and flotation waste dumps, whose contaminated water drained directly into Kamenicka River. The increased lead, zinc and associated metals are risk for the human environment along the Kamenicka River, which flows into the Kamenica Lake.

Organization of the both Access databases was carried out under the several main topics, which are in accordance with the principles of GIS related mineral databases given elsewhere [1], [2], [3], [4], [5], [6], [7].

\section{DISCUSSION}

The particular mineral database itself was structured under the following main topics:

General information where has been enclosed information about the mining company, status, latitude/longitude, ore district name, comments etc. (Figure 1).

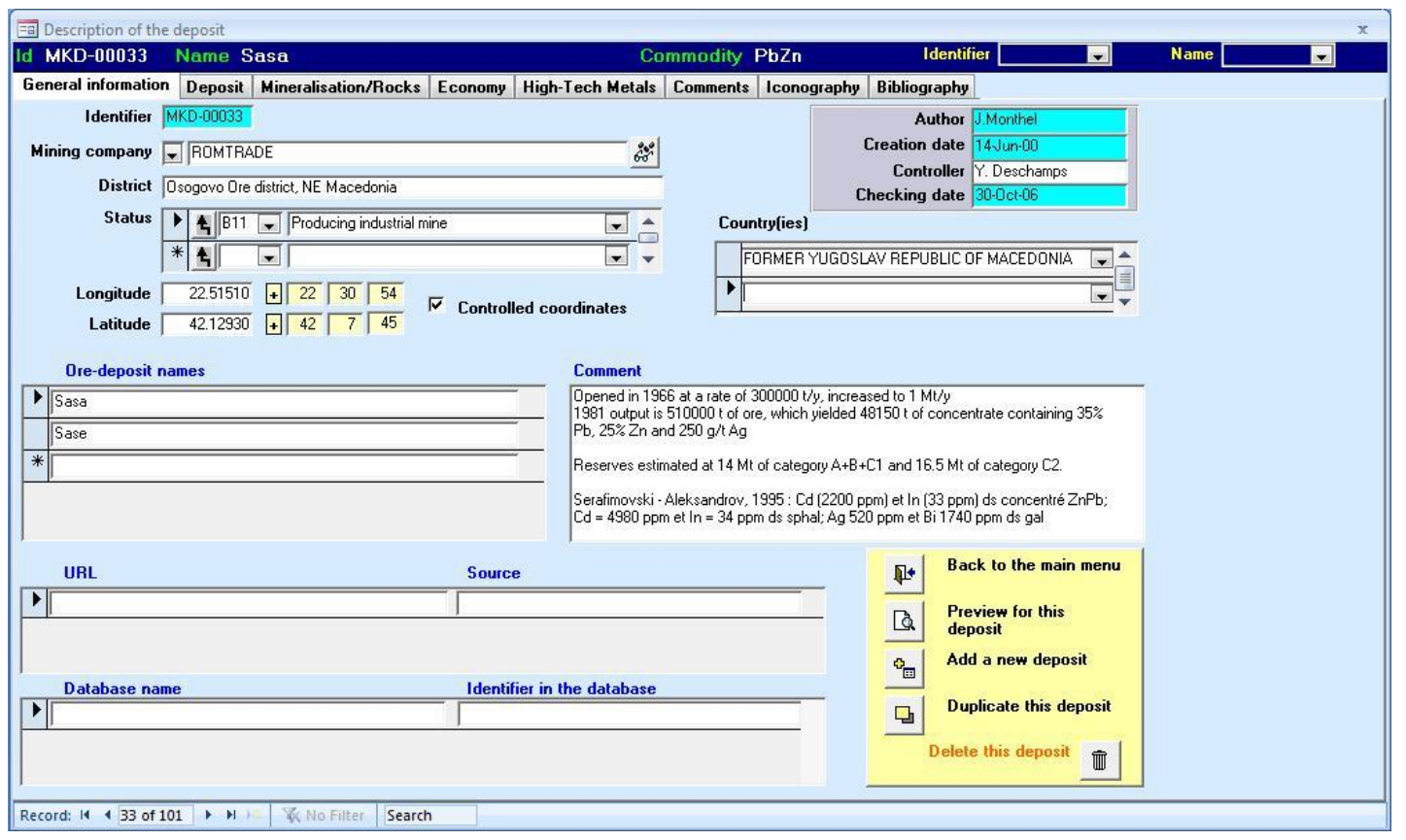

Fig. 1. General information datasheet of the database

For example on our sample of the Sasa deposit-mine we stressed out that is a producing $\mathrm{Pb}-\mathrm{Zn}$ mine, which production has started back in 1966, followed by detailed coordinates and name of the company owner of the mine and production facility, as well as familiar names used by locals for the mine and short general comments.

Deposit features sheet is organized in a manner that should be given details about the parameters: deposit type, main morphology and secondary morphology (Figure 2).

On our example deposit, Sasa, we have entered data about the deposit type where we have pointed out that is the $\mathrm{Pb}-\mathrm{Zn} \pm \mathrm{Ag}$ skarn deposit with elements of atypical volcanosedimentary morphology (both primary and secondary). 


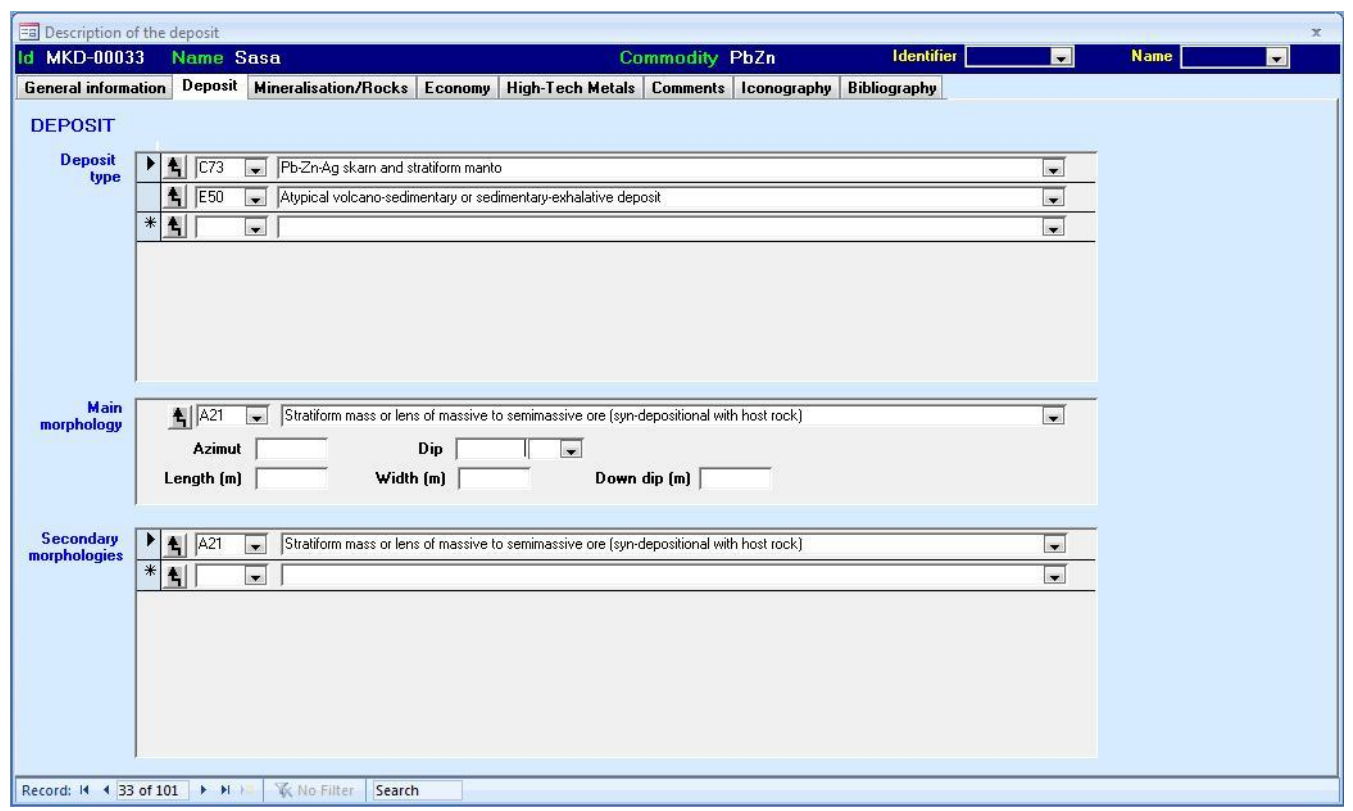

Fig. 2. Deposit features datasheet of the database

Mineralization/Rocks data sheet usually should contain data about age (supposed and absolute), ore mineralogy, gangue mineralogy, hydrothermal alteration, host rock (age supposed/absolute, host rock formation, name and lithology). All of them being grouped into separate main windows (Figure 3).

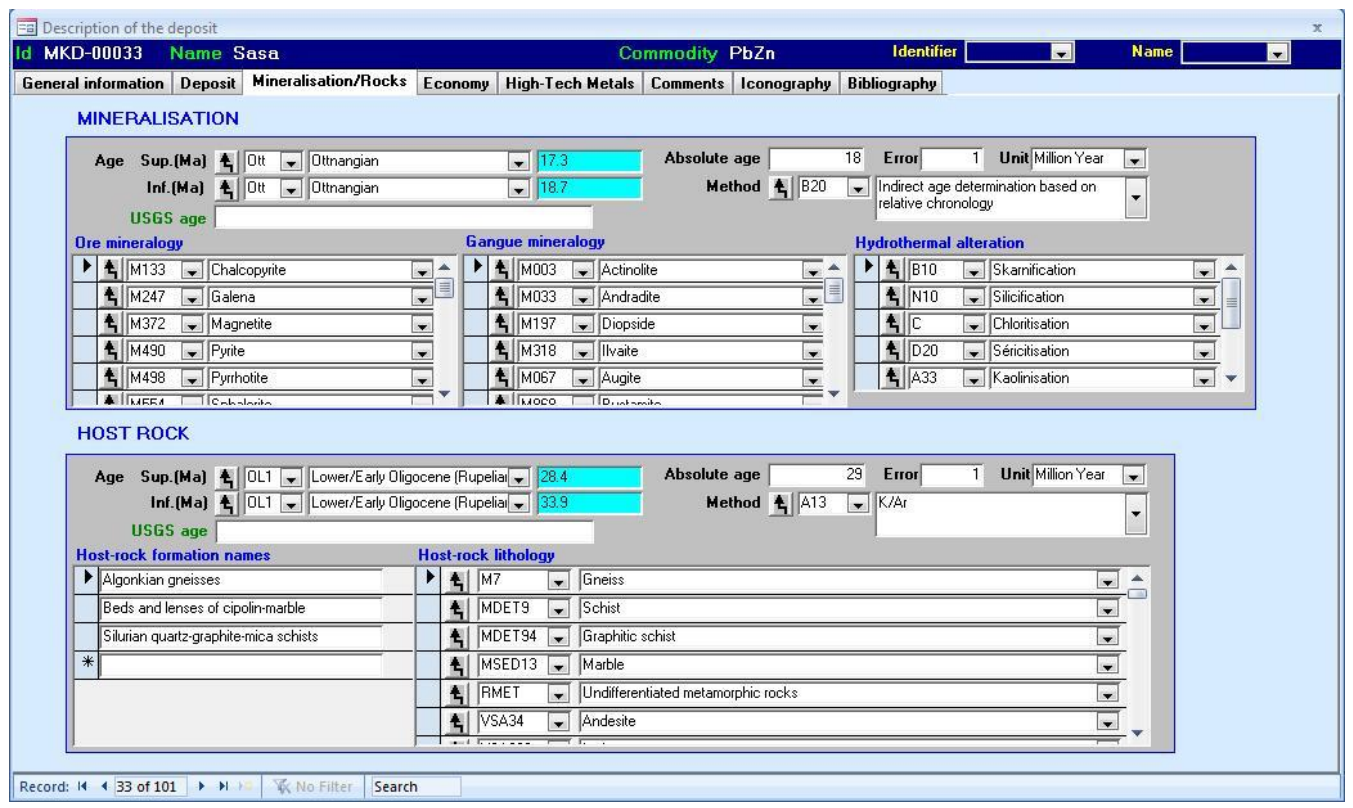

Fig. 3. Mineralization-rocks information datasheet of the database

Here we have entered a significant amount of data regarding the mineralization age (relative 17.3-18.7 Ma; absolute 18), ore mineralogy (galena, sphalerite, chalcopyrite, pyrite, magnetite, pyrrhotite, etc.), gangue mineralogy (actinolite, andradite, diopside, ilvaite, augite etc.) and diverse hydrothermal alterations (skarnification, silicification, sercitization, chloritization, kaolinization etc.). After that followed an information about 
the host rock age (relative 28.4-33.9 Ma; absolute 29, K/Ar method) and host rock lithology (gneiss, schist, graphic schist, marble, andesite etc.).

Economy data sheet was planned to provide an information about ore type, grade unit, former production, average grade of production, years of exploitation, reserves, average grade, type of reserves, resources, average grade of resources, type of resources organized in windows named exploitation type, main commodity and commodity (Figure 4).

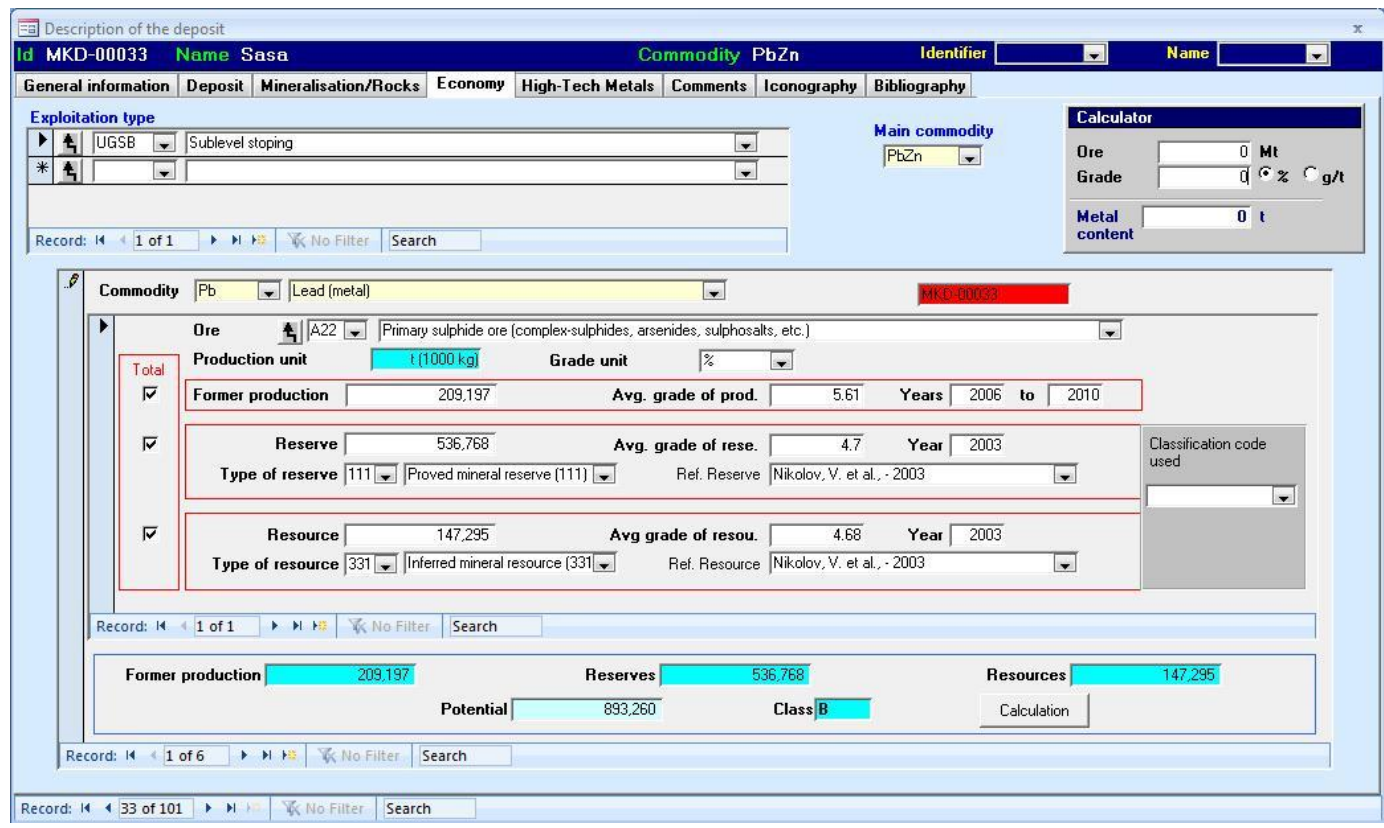

Fig. 4. Economy information datasheet of the database

Here for the Sasa deposit, was given information about the exploitation type of mining (underground) where the main commodities, $\mathrm{Pb}-\mathrm{Zn}$, are represented by primary sulfide ore (complex sulfides, sulphosalts etc.). Also, reserves has been quoted as former production in amount of $209197 \mathrm{t}$ (period 2006-2010 and lead concentration of 5.61\% Pb), proved mineral reserves of $536768 \mathrm{t}$ (as of 2003 and lead concentration of $4.7 \% \mathrm{~Pb}$ ) as well as indicated reserves of $147295 \mathrm{t}$ (as of 2003 and lead concentration of $4.68 \% \mathrm{~Pb}$ ) and all of them followed by data about four additional commodities ( $\mathrm{Zn}, \mathrm{Cd}, \mathrm{Ag}, \mathrm{In}$ ) given as separate records within this datasheet (metal production, not the raw ore).

High-Tech Metals information sheet was divided into two different windows, which have been established in order to characterize (i) Potential of specific commodities (e.g. Li, Ga, Ge, $\mathrm{Se}, \mathrm{In}, \mathrm{Re} . .$. ) which interest had growing since the last decade and (ii) where the anthropogenic products are processed. To characterize High-Tech metals, user has to enter a commodity (ex. $\mathrm{Re}, \mathrm{Se}, \mathrm{Ga} . .$. ), and then he will be able to give information about host minerals (e.g. molybdenite), grades (i.e. minimum, maximum and average grade) and abundance of host minerals in the ore. The right window give information about processing site(s) (e.g. concentrator, mill, smelter...). Due to complex use of metals from the Sasa deposit, where few metals are extracted beside the main one-lead-zinc (Ag, In etc.), we haven't entered any additional data regarding this information sheet of the database.

Comments sheet, which is composed of two windows where it is possible to write free texts describing details about geology and/or details about economy of a particular deposit gives a 
fine opportunity to describe particular deposit in more details (Figure 5). Here we haven't entered any data, since we did that in the first sheet (see Figure 1).

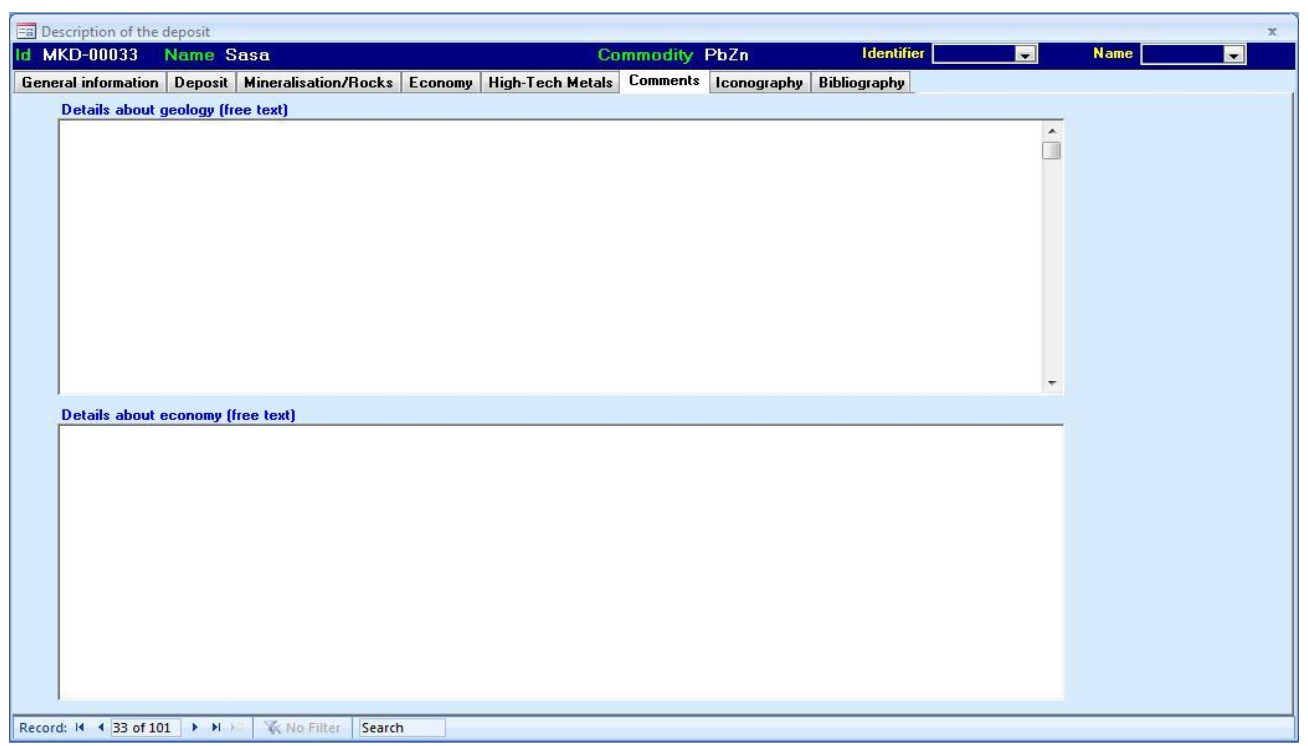

Fig. 5. Comments information datasheet of the database

In the lower window intended for data about the economy could be entered all significant data such are annual mine capacity, quantitative-qualitative parameters of produced ore, facility (facilities) where the raw excavated ore has been processed etc.

Iconography sheet has been elaborated in order to attach images with a deposit (Figure 6).

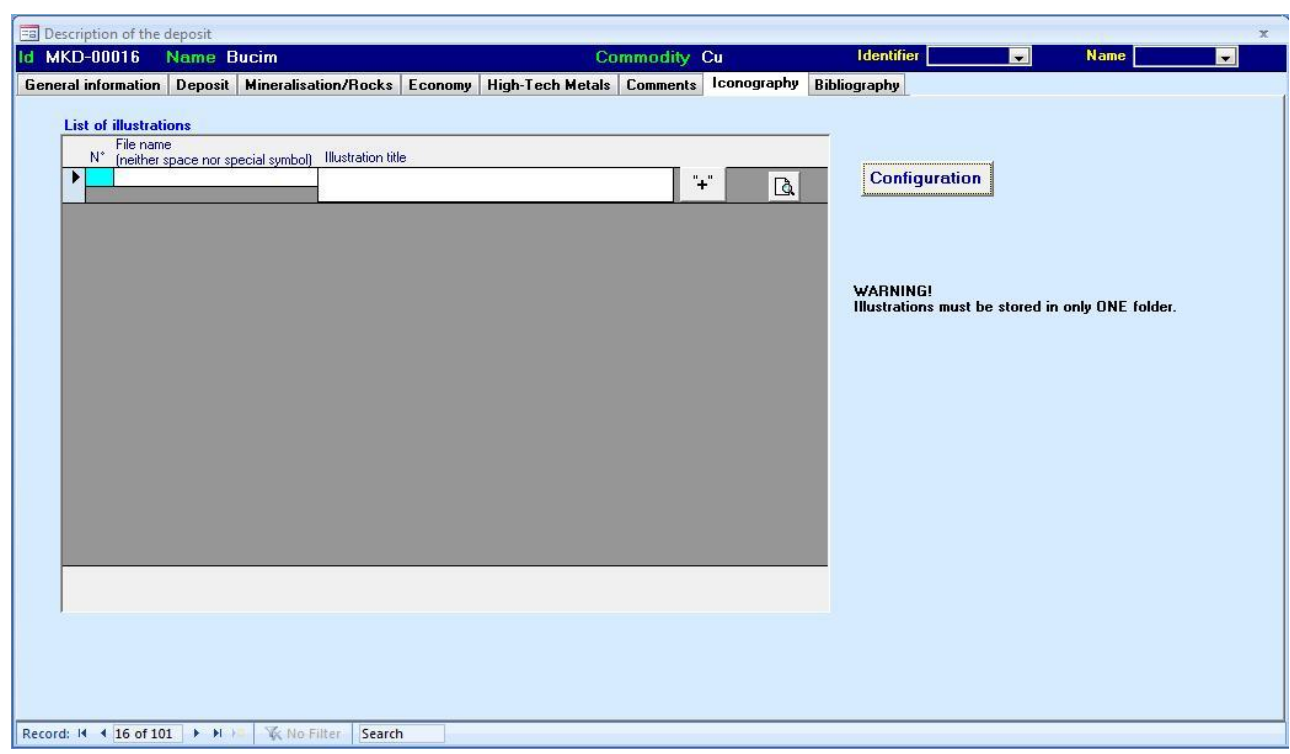

Fig. 6. Iconography information datasheet of the database

The first step being definition of paths of the image directory and the image viewer (e.g. Photo Editor, Windows picture viewer, Picasa...) by clicking on "Configuration" button (Figure 6).

Bibliography data sheet for a particular deposits was intended to give an overview of geological bibliography (references relating to the geology of the deposit) and economical bibliography (references relating to economic data of the deposit) as can be seen at Figure 7 . 


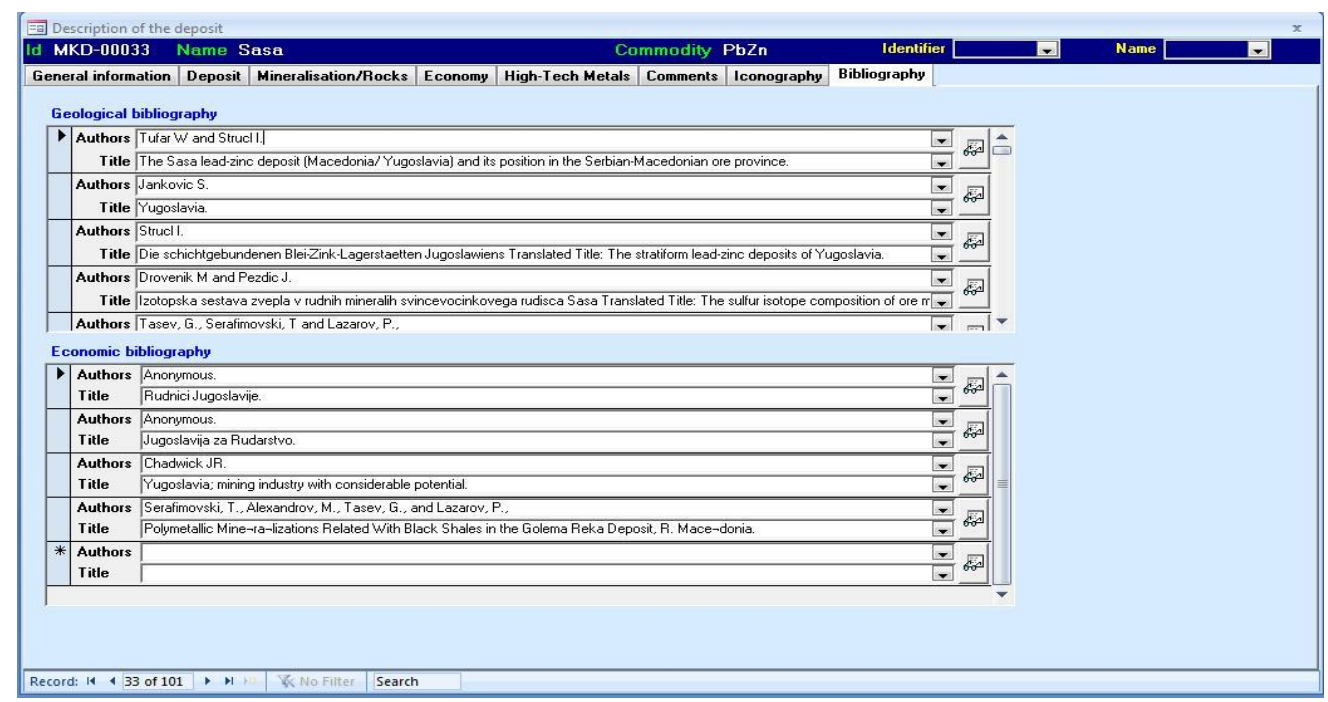

Fig. 7. Bibliography information datasheet of the database

For the Sasa deposit, we made significant input in regards to both types of bibliography, geological and economical ones. All the known and commonly used references to this particular deposit has been covered in this data sheet.

In regards to the anthropogenic concentrations Access database we would like to display its several organizational entities:

General information address information about the location, status, latitude/longitude, ore district name, comments etc. (Figure 8).

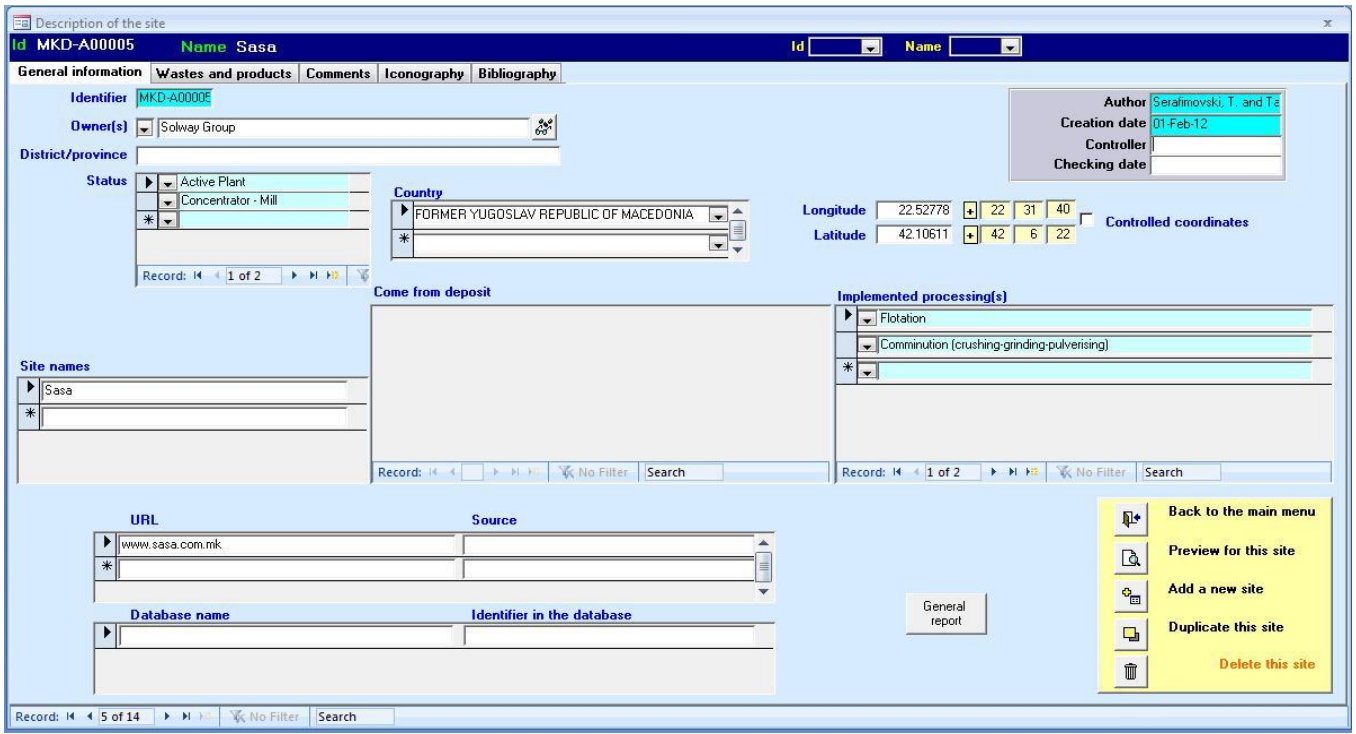

Fig. 8. General information datasheet of the anthropogenic database

For the Sasa deposit-mine related anthropogenic concentrations, we stressed out that is a an active facility with description of implemented processing methods, followed by coordinates, familiar names used by locals for the mine and short general comments.

Wastes and products sheet is organized in a manner that gives details about: type of waste storage (surface), type of waste (flotation tailings), volume and surface occupied 
as well as tonnage and density of a particular waste-product, waste mineralogy, particular commodity and affected water area (Figure 9). Here potential of specific commodities in the anthropogenic products (e.g. $\mathrm{Ga}, \mathrm{Ge}, \mathrm{In}, \mathrm{Ce}, \mathrm{Ag}, \mathrm{Cd}, \mathrm{Cu} \ldots$...) related to certain host minerals was given, as well as grades (i.e. minimum, maximum and average grade) and abundance of host minerals in anthropogenic products. For ours particular locality, Sasa, we have entered data about all different kinds of present waste minerals (galena, sphalerite, pyrite, bismuthinite, polybasite etc.).

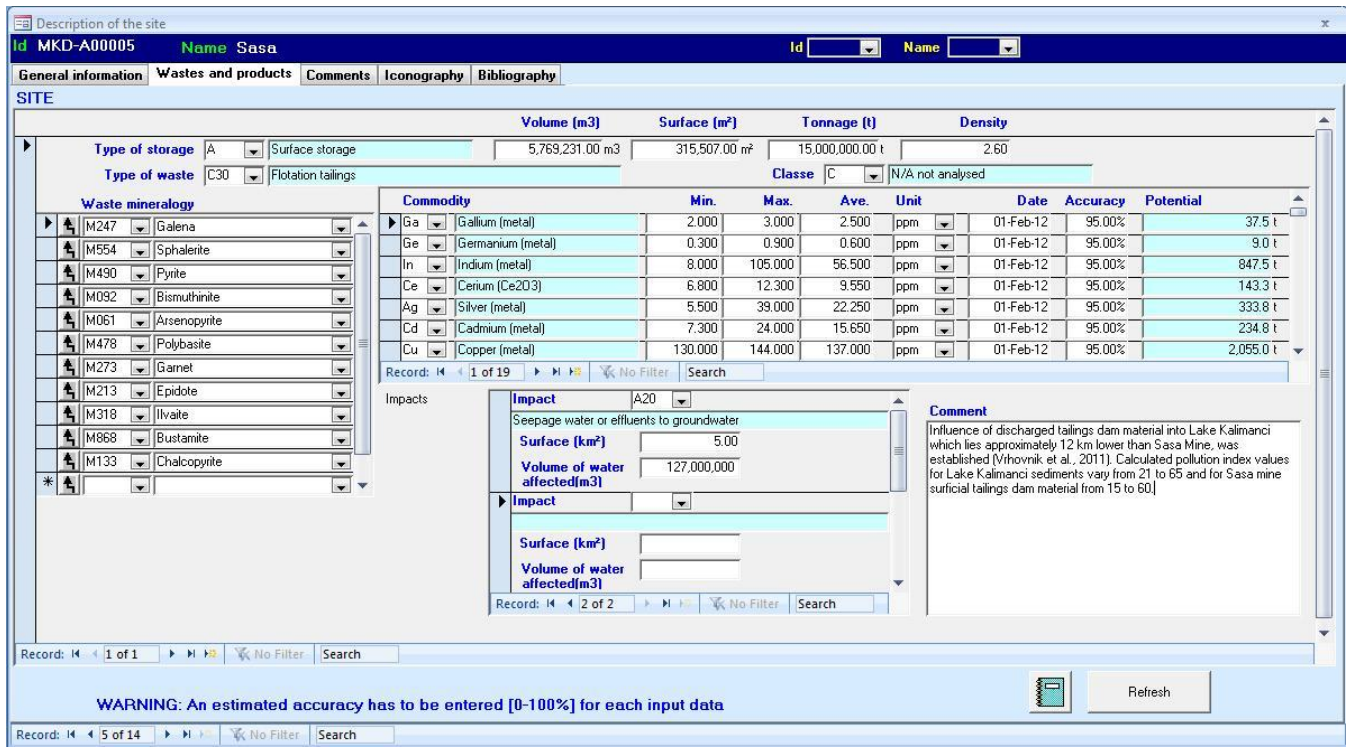

Fig. 9. Wastes and products datasheet of the anthropogenic database

Comments sheet, which is composed of space where it is possible to write free texts describing details about geology and/or details about economy of a particular deposit related to the anthropogenic concentrations gives a fine opportunity to describe details about the mining history of the locality with its representative economic features, past annual mine capacity, quantitative-qualitative parameters of produced ore, facility where the raw excavated ore has been processed etc (Figure 10).

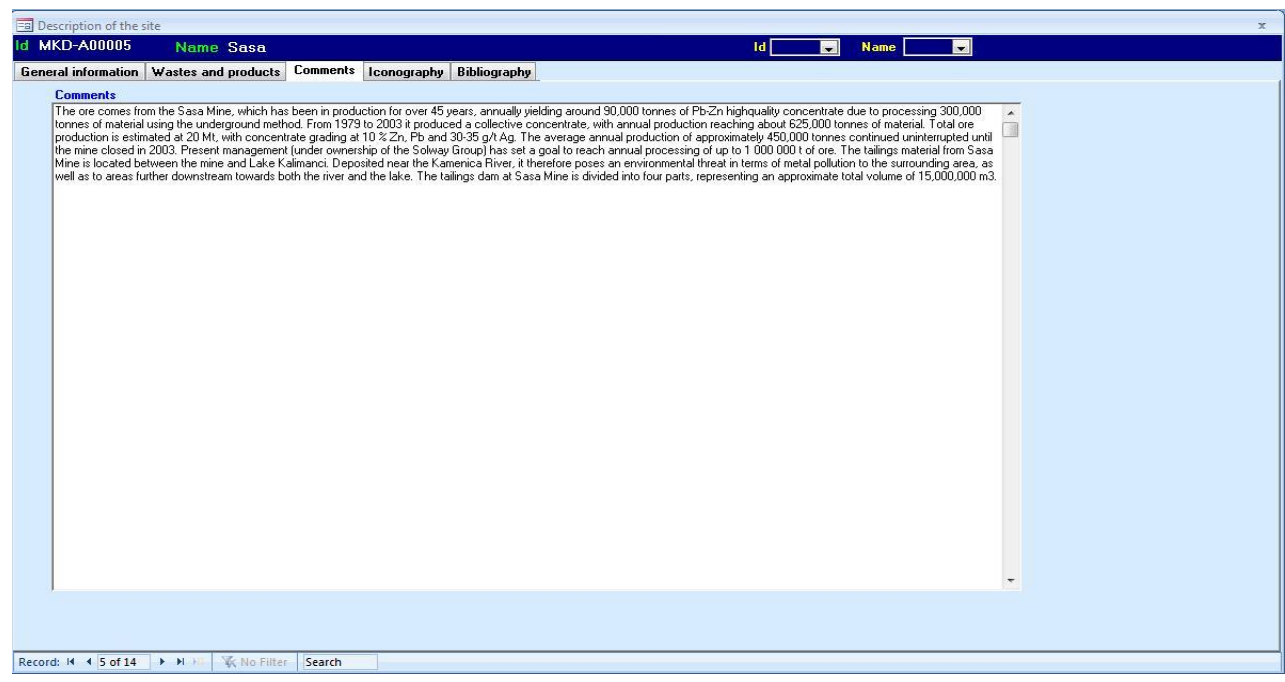

Fig. 3. Comments information datasheet of the anthropogenic database 
Iconography sheet has been elaborated in order to attach images with an anthropogenic concentration. The first step being definition of paths of the image directory and the image viewer (e.g. Photo Editor, Windows picture viewer, Picasa...) by clicking on "Configuration" button quite similar to the mineral database above (Figure 6).

Bibliography data sheet for particular anthropogenic concentrations was intended to give an overview of available bibliography (references relating to the anthropogenic concentrations) and economical bibliography (references relating to economic data of the anthropogenic concentrations) and organizationally was quite similar to the previous database seen at Figure 7.

\section{CONCLUSION}

The attempt to establish the Access database for specific examples of metallic raw materials and its anthropogenic reflections, at the territory of the Republic of Macedonia, was successfully implemented. The major accents in the database systematization were given to the qualitative-quantitative parameters and natural indicators in function to present and future valorization of metals (copper, gold, lead, zinc, silver, iron, nickel etc.) that were subject to the establishment of the database, in accordance with professional mineral and anthropogenic concentration Access databases.

\section{References}

[1] Albert, J.H., and Rossman, A.J., 2001, Workshop statistics: Discovery withdata, a Bayesian approach: Emeryville, Key College Publishing, 350 p.

[2] Barnett, C.T., and Williams, P.M., 2006, Mineral exploration using modern data mining techniques: Society of Economic Geologists, Special Publica-tion 12, p. 295-310

[3] Cassard, D. and Itard, Y. (2003): Metallogenic and envi-ronmental information systems: A modern tool forthe sustainable development of mineral resources.In: Tvalchrelidze, A.G. and Morizot, G. (eds.): Mineral resource base of the Southern Caucasus and sys-tems for its management in the XXI century, NATOScience Series, IV. Earth and Environmental Sciences, 17, 167-180.

[4] Goodchild, M. and Dopal, S., 1989. Accuracy of spatial databases. Taylor \& Francis, London.

[5] Harris, J.R., Wilkinson, L., Heather, K., Fumerton, S.,Bernier, M.A., Ayer, J. and Dahn, R. (2001): Application of GIS processing techniques for producingmineral prospectivity maps-a case study: mesother-mal $\mathrm{Au}$ in the Wayze Greenstone Belt, Ontario, Canada. Natural Resources Research, 10, 91-124

[6] Itard, Y., Geiller, M., Cassard, D. and Lips, A.L.W. (2002):Environmental dimension of a regional metallogenic synthesis: a way towards a sustainable extractive industry. GIS in Geology Int. Conference, Vernadsky SGM RAS, November 13-15, 2002, Moscow,Extended abstracts volume, 51-53.

[7] Vuollo, J., Cassard, D., Simons, B. and Seymon, A., 2010. The Earth resource data exchange model (EarthResourceML)-a tool for delivering ProMine and INSPIRE mineral resource data: INSPIRE Conference 2010 Presentation, Krakow, Poland, 37 p 